\title{
Evaluation of the efficacy of factors influencing on marketing SMEs
}

\author{
Mona Yaghoubi* and Ali Alikhani
}

Department of Accounting and Management, North Tehran Branch, Islamic Azad University, Tehran, Iran

\begin{tabular}{|c|c|}
\hline C H R O N I C L E & A B S T R A T \\
\hline $\begin{array}{l}\text { Article history: } \\
\text { Received January 14, } 2014 \\
\text { Accepted 10 June 2014 } \\
\text { Available online } \\
\text { June 20 2014 } \\
\text { Keywords: } \\
\text { Marketing } \\
\text { SMEs } \\
\text { Innovation } \\
\text { Handmade carpet }\end{array}$ & $\begin{array}{l}\text { This paper presents an empirical investigation to study the effects of different factors } \\
\text { influencing on marketing in small and medium enterprises (SMEs) in city of Tehran, Iran. The } \\
\text { study has been accomplished among } 57 \text { SMEs out of } 70 \text { active business units who were } \\
\text { involved in hand made carpet. The survey uses a questionnaire originally developed by } \\
\text { Merrilees et al. (2011) [Merrilees, B., Rundle-Thiele, S., \& Lye, A. (2011). Marketing } \\
\text { capabilities: Antecedents and implications for B2B SME performance. Industrial Marketing } \\
\text { Management, 40(3), 368-375.] to determine the factors influencing on marketing SMEs. Using } \\
\text { structural equation modeling, the results of survey indicate that market orientation, management } \\
\text { capability, innovation capability and brand capability of SME's marketing performance } \\
\text { influence on development of marketing, positively. }\end{array}$ \\
\hline
\end{tabular}

(C) 2014 Growing Science Ltd. All rights reserved.

\section{Introduction}

These days, many small to medium-sized enterprises (SMEs) cannot perform conventional marketing because of the limitations of resources, which exist to all SMEs. It is also because SME owner/managers behave and think differently from conventional marketing decision-making practices in large firms Gilmore et al. (2001) concentrated on SME characteristics and how these influence on marketing characteristics within SMEs. In a search for "alternative" marketing techniques, the inherent existence of the owner/manager's "network" in its different guises such as personal contact networks, social networks, business networks and industry and marketing networks and how these networks were applied was taken into account. Dobni and Luffman (2003) identified ideal behavioral profiles for organizations looking for maximization of performance by looking into the scope and effect of market orientation on strategy implementation. Reijonen (2010) provided some insights of how the concept of marketing was considered and put into practice in SMEs. In addition, the study examined whether the perceptions and practices differ according to the size, industry and customers of the SMEs. In this survey, marketing informed the customers about the enterprise and its offerings.

*Corresponding author. Tel: +989126432720

E-mail addresses: monayaghoubi68@gmail.com (M. Yaghoubi) 
SME marketers were also interested in building customer relationships. Marketing thought and practices could not be regarded as being uniform within SMEs.

\section{The proposed study}

This paper presents an empirical investigation to study the effects of different factors influencing on marketing in SMEs. The study has been accomplished among 57 SMEs out of 70 active business units in hand made carpet. The survey uses a questionnaire originally developed by Merrilees et al. (2011) to determine the factors influencing on marketing SMEs. Fig. 1 demonstrates the proposed study of this paper,

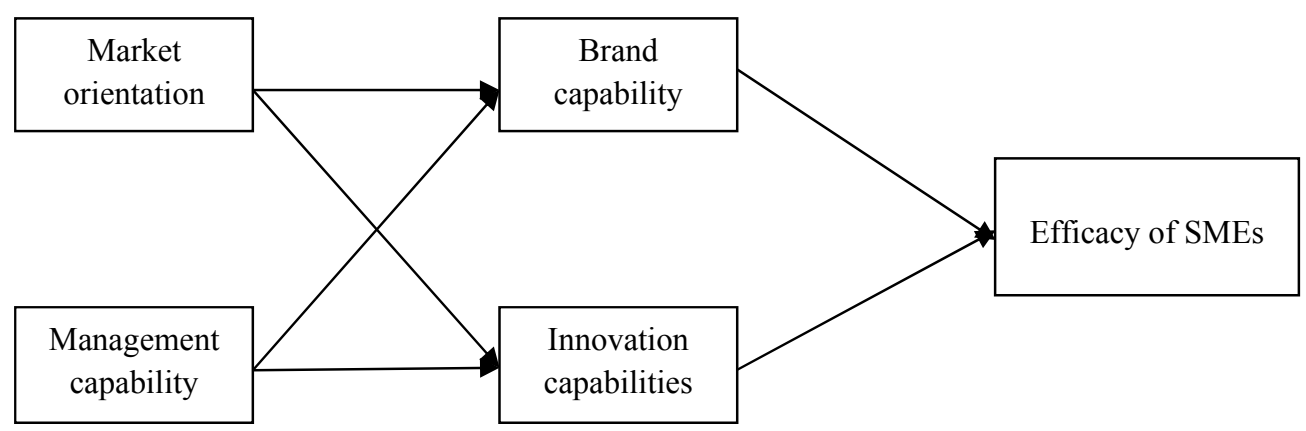

Fig. 1. The proposed study

According to Fig. 1, the following hypotheses are considered for the proposed study of this paper.

1. Market orientation influences positively on innovation capabilities.

2. Market orientation influences positively on brand capability.

3. Management capability influences positively on innovation capabilities.

4. Management capability influences positively on brand capability.

5. Innovation capabilities influences positively on efficacy of SMEs.

6. Brand capability influences positively on efficacy of SMEs.

The population of this study includes all active SMEs on hand made carpet in city of Tehran, Iran. The sample size is calculated as follows,

$n=\frac{N \times z_{\alpha / 2}^{2} \times p \times q}{\varepsilon^{2} \times(N-1)+z_{\alpha / 2}^{2} \times p \times q}$,

where $N$ is the population size, $p=1-q$ represents the yes/no categories, $z_{\alpha / 2}$ is CDF of normal distribution and finally $\varepsilon$ is the error term. Since we have $p=0.5, z_{\alpha / 2}=1.96$ and $N=70$, the number of sample size is calculated as $n=57$. Cronbach alpha has been calculated as 0.93 , which is well above the minimum acceptable level of 0.70 .

\subsection{Personal characteristics of the participants}

In our survey, $29.9 \%$ of the participants were male and the remaining $70.1 \%$ of them were female. Fig. 2 shows details of other personal characteristics of the participants. 


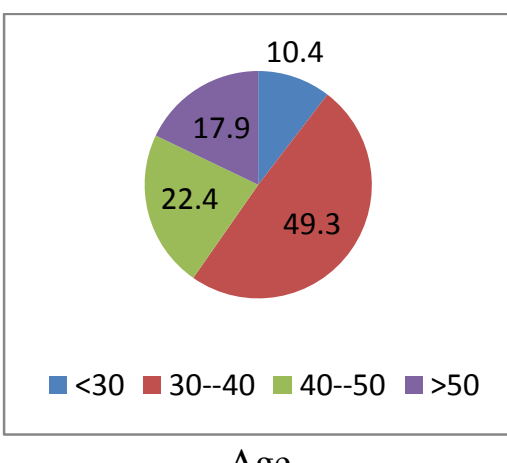

Age

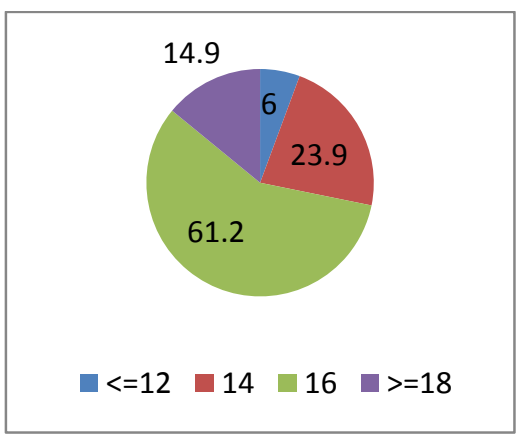

Years of education

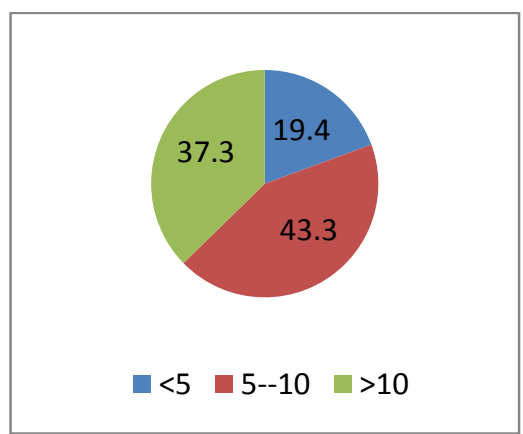

Job experience

Fig. 2. Personal characteristics of the participants

As we can observe from the results of Fig. 2, most participants were middle-aged people with good educational backgrounds as well as job experiences. Table 1 shows details of some basic statistics associated with various components of the survey.

\section{Table 1}

The summary of some basic statistics

\begin{tabular}{lcccc}
\hline Variable & Average variance explained & Combined Reliability & $\mathrm{R}^{2}$ & Cronbach alpha \\
\hline Market orientation & 0.521 & 0.895 & 0 & 0.863 \\
Management capability & 0.551 & 0.895 & 0 & 0.873 \\
Brand capability & 0.801 & 0.953 & 0.344 & 0.938 \\
Innovation capability & 0.723 & 0.929 & 0.248 & 0.904 \\
Efficiency of SMEs & 0.386 & 0.757 & 0.424 & 0.748 \\
\hline
\end{tabular}

In addition, Kolmogorov-Smirnov test has indicated that all components of the survey were normally distributed and we may use parametric test to verify the hypotheses of the survey. Table 2 shows details of Pearson correlation test.

\section{Table 2}

The summary of Pearson correlation ratios

\begin{tabular}{|c|c|c|c|c|c|}
\hline Variable & $\begin{array}{c}\text { Market } \\
\text { orientation }\end{array}$ & $\begin{array}{c}\text { Management } \\
\text { capability }\end{array}$ & $\begin{array}{c}\text { Brand } \\
\text { capability }\end{array}$ & $\begin{array}{l}\text { Innovation } \\
\text { capability }\end{array}$ & $\begin{array}{l}\text { Efficiency of } \\
\text { SMEs }\end{array}$ \\
\hline Market orientation & 1.00 & & & & \\
\hline Management capability & 0.561 & 1 & & & \\
\hline Brand capability & 0.533 & 0.502 & 1 & & \\
\hline Innovation capability & 0.442 & 0.438 & 0.255 & 1 & \\
\hline Efficiency of SMEs & 0.636 & 0.713 & 0.549 & 0.478 & 1 \\
\hline
\end{tabular}

The results of Table 2 indicate that there were some positive and meaningful relationships between various components of the survey. Table 3 shows details of some statistical observations on three questionnaires of the study.

\section{Table 3}

The summary of some statistical observation on the SEM implementation

\begin{tabular}{lccccccc}
\hline Variable & NFI & RMSEA & Chi-Square/df & GFI & AGFI & CFI & IFI \\
\hline Values & 0.93 & 0.042 & 2.081 & 0.92 & 0.92 & 0.96 & 0.96 \\
Desirable level & $>0.90$ & 0.1 & $<3$ & $>0.90$ & $>0.90$ & $>0.90$ & $>0.90$ \\
Result & Desirable & Desirable & Desirable & Desirable & Desirable & Desirable & Desirable \\
\hline RMSEA = Root-mean-square error of approximation AGFI = Adjusted goodness-of-fit index CFI = comparative good fitness GFI = Goodness-of-fit index & &
\end{tabular}

The results of Table 3 confirm that all components of the survey are within acceptable levels and this confirms the results of the survey. 


\section{The results}

In this section, we present details of our findings on testing all hypotheses of the survey and they are summarized in Table 4 as follows,

\section{Table 4}

The summary of testing hypotheses of the survey

\begin{tabular}{lccc}
\hline Hypothesis & $\beta$ & t-value & Result \\
\hline Market orientation $\rightarrow$ innovation capabilities & 0.367 & 4.037 & Confirmed \\
Market orientation $\rightarrow$ brand capability & 0.287 & 2.568 & Confirmed \\
Management capability $\rightarrow$ innovation capabilities & 0.296 & 3.470 & Confirmed \\
Management capability $\rightarrow$ brand capability & 0.277 & 2.603 & Confirmed \\
Innovation capabilities $\rightarrow$ efficacy of SMEs & 0.457 & 4.797 & Confirmed \\
Brand capability $\rightarrow$ efficacy of SMEs & 0.361 & 4.022 & Confirmed \\
\hline
\end{tabular}

\section{Conclusion}

In this paper, we have presented an empirical investigation to study the effects of various factors on marketing SMEs. The proposed study has confirmed that Market orientation influences positively on innovation capabilities, Market orientation influences positively on brand capability, Management capability influences positively on innovation capabilities, Management capability influences positively on brand capability. In addition, Innovation capabilities influences positively on efficacy of SMEs and finally, Brand capability influences positively on efficacy of SMEs. The results of survey have confirmed all hypotheses of the survey. The results of our survey are consistent with findings of Tang (1998), Keh et al. (2007) and Reuber and Fischer (1997).

\section{Acknowledgement}

The authors would like to thank the anonymous referees for constructive comments on earlier version of this paper.

\section{References}

Dobni, C. B., \& Luffman, G. (2003). Determining the scope and impact of market orientation profiles on strategy implementation and performance. Strategic Management Journal, 24(6), 577-585.

Gilmore, A., Carson, D., \& Grant, K. (2001). SME marketing in practice. Marketing Intelligence \& Planning, 19(1), 6-11.

Keh, H. T., Nguyen, T. T. M., \& Ng, H. P. (2007). The effects of entrepreneurial orientation and marketing information on the performance of SMEs. Journal of Business Venturing, 22(4), 592611.

Merrilees, B., Rundle-Thiele, S., \& Lye, A. (2011). Marketing capabilities: Antecedents and implications for B2B SME performance. Industrial Marketing Management, 40(3), 368-375.

Reijonen, H. (2010). Do all SMEs practise same kind of marketing?. Journal of Small Business and Enterprise Development, 17(2), 279-293.

Reuber, A. R., \& Fischer, E. (1997). The influence of the management team's international experience on the internationalization behaviors of SMEs. Journal of International Business Studies, 28(4), 807-825.

Tang, H. K. (1998). An integrative model of innovation in organizations. Technovation, 18(5), 297309. 